\title{
ANALISIS PERUBAHAN GARIS PANTAI MENGGUNAKAN DATA PENGINDERAAN JAUH DI PANTAI CERMIN, KABUPATEN SERDANG BEDAGAI
}

\author{
Andrian Lozi, Riki Rahmad \\ Jurusan Pendidikan Geografi, Fakultas Ilmu Sosial, Universitas Negeri Medan \\ Jalan William Iskandar Pasar V Medan Estate, 20211 Sumatera Utara \\ Email corresponding: lozisyahputra0@gmail.com
}

\begin{abstract}
Abstrak
Artikel ini ditulis untuk mengetahui yaitu penggunaan data penginderaan jauh yang dihasilkan oleh teknologi penginderaan jauh untuk menganalisis perubahan garis pantai di Pantai Cermin Kabupaten Serdang Bedagai. Metode yang dilakukan dalam penelitian ini adalah deskriptif kuantitatif yaitu menentukan sebaran, luasan dan perubahan tutupan lahan yang diperoleh dengan menganalisis Citra Landsat 45 pada tahun 2007 dan Citra Landsat 2017 tentang perubahan garis pantai berdasarkan citra 2007 dan tumpangsusun (overlay) dengan citra klasifikasi tahun 2017. Berdasarkan hasil dari interpretasi yang di lakukan dengan menggunakan software ArcGIS 10.5 maka di dapatkan luas wilayah di Kecamatan Pantai Cermin yang bertambah pada tahun 2007 dan 2017 mencapai 1481798 km². Penambahan wilayah tersebut tersebar di sepanjang pesisir kawasan Kecamatan Pantai Cermin, serta dengan rata - rata pengikisan oleh abrasi air laut sebesar 1249322 Km² per tahunnya, dengan penambahan tepi pantai yang cukup signifikan per tahunnya.
\end{abstract}

Kata Kunci: Perubahan Garis Pantai, Abrasi, Sedimentasi, Landsat

\begin{abstract}
This article was written to find out that the use of remote sensing data produced by remote sensing technology to analyze shoreline changes at Serdang Bedagai District Mirror Beach. The method carried out in this study was to determine the distribution, extent and change of land cover obtained by analyzing 4-5 Landsat Imagery in 2007 and 2017 Landsat Imagery of shoreline changes based on the 2007 image and superimposition with the 2017 classification image. Based on the results of the interpretations carried out using ArcGIS 10.5 software, the area of Pantai Cermin Subdistrict, which was increased in 2007 and 2017, reached $1481798 \mathrm{~km}^{2}$. The addition of the area is spread along the coastal area of Pantai Cermin Subdistrict, as well as with the erosion rate by sea water abrasion of $1249322 \mathrm{Km}^{2}$ per year, with the addition of a significant beach edge per year.
\end{abstract}

Key words: coastline changes, Abrasion, Sedimentation, Landsat

\section{PENDAHULUAN}

Lingkungan pantai merupakan suatu wilayah yang selalu mengalami perubahan. Perubahan lingkungan pantai dapat terjadi secara lambat hingga cepat, tergantung dari faktor yang mempengaruhinya. Perubahan garis pantai ditunjukkan oleh perubahan kedudukannya, tidak hanya ditentukan oleh suatu faktor tunggal tapi oleh sejumlah faktor beserta interaksinya yang merupakan hasil gabungan dari proses alam dan manusia. Faktor alami berasal dari pengaruh proses-proses hidro-oseanograf yang terjadi di laut seperti hempasan gelombang, perubahan pola arus, variasi pasang surut, serta perubahan iklim.

Penginderaan jauh dapat diartikan sebagai teknologi untuk mengidentifikasi suatu obyek di permukaan bumi tanpa melalui kontak langsung dengan obyek tersebut. Saat ini teknologi penginderaan jauh berbasis satelit menjadi sangat populer dan digunakan untuk berbagai tujuan kegiatan, salah satunya untuk 
mengidentifikasi potensi sumber daya wilayah pesisir dan lautan. Hal ini disebabkan teknologi ini memiliki beberapa kelebihan, seperti: harganya yang relatif murah dan mudah didapat, adanya resolusi temporal (perulangan) sehingga dapat digunakan untuk keperluan monitoring, cakupannya yang luas dan mampu menjangkau daerah yang terpencil, bentuk datanya digital sehingga dapat digunakan untuk berbagai keperluan dan ditampilkan sesuai keinginan.

Banyak sekali wilayah-wilayah di Indonesia yang terus mengalami perubahan garis pantai. Salah satunya adalah wilayah Kabupaten Langkat. Upaya manusia dalam memanfaatkan kawasan pantai sering tidak dilandasi pemahaman yang baik tentang perilaku pantai. Akibatnya, berbagai masalah pantai bermunculan. Salah satunya adalah proses abrasi dan sedimentasi garis pantai (Awaliah, 2013). Proses abrasi dan sedimentasi garis pantai pada mulanya timbul secara alami, akan tetapi proses akan berlangsung lebih cepat jika pembangunan sarana kepentingan manusia tidak didasari dengan pengetahuan yang baik tentang perilaku proses dinamika perairan pantai, dalam hal ini perubahan garis pantai (Dewi, 2011 dalam Awaliah dkk, 2013). Teknologi yang mudah dan cepat untuk pemantauan perubahan garis pantai adalah dengan menggunakan teknologi penginderaan jauh melalui perekaman citra satelit sebagai datanya. Salah satunya adalah dengan menggunakan data hasil perekaman citra Landsat (Land satellite) Taofiqurohman (2012).

Kawasan pantai bersifat dinamis, artinya ruang pantai (bentuk dan lokasi) berubah dengan cepat sebagai reaksi terhadap proses alam dan aktivitas manusia (Solihuddin, 2010). Aktivitas manusia dalam memanfaatkan sumber kekayaan di kawasan pantai sering tumpang tindih, sehingga tidak jarang kesehatan ekosistem pantai menjadi turun.

Garis pantai merupakan batas dari ekosistem laut dan ekosistem darat yang dalam pengolahannya kedua ekosistem ini memiliki karakteristik yang berbeda. Garis pantai juga berguna dalam penentuan batas wilayah Negara atau pun daerah untuk pengolahan sumberdaya alam yang ada contohnya ZEE diukur sejauh 200 mil dari garis pantai kearah laut lepas, kemudian UU No. 22 Tahun 1999, Pasal 3 menyatakan bahwa "Wilayah Daerah Provinsi terdiri atas wilayah darat dan wilayah laut sejauh dua belas mil laut yang diukur dari garis pantai ke arah laut lepas dan/atau ke arah perairan kepulauan". Pemanfaatan lahan di Pantai Timur Sumatera Utara sebagian besar untuk pemukiman, tambak, obyek wisata dan lain - lain. Akibat dari pemanfaatan lahan tersebut pantai mengalami perubahan, hal ini juga disebabkan oleh pemanfaatan lahan di sekitar DAS. Perubahan pantai di Pantai Timur Sumatera Utara juga oleh proses deposisi yang mengakibatkan perkembangan pantai di daerah muara sungai maupun sepanjang pantai. Material yang mengendap biasanya berasal dari aliran sungai serta material dari laut yang terbawa oleh arus dan gelombang.

Lingkungan pantai merupakan wilayah yang selalu mengalami perubahan, karena menjadi tempat bertemunya dua faktor yang berasal dari daratan dan dari lautan, garis pertemuan antara daratan dan lautan inilah yang disebut dengan garis pantai (Istiono 2011). Perubahan lingkungan pantai diakibatkan oleh gerakan angin yang membangkitkan gerombang sehingga dapat menyebabkan terjadinya perubahan garis pantai (Tawas dan Pingkan 2016). Perubahan garis pantai merupakan satu proses secara terus menerus melalui berbagai proses baik pengikisan (abrasi) maupun penambahan (akresi) pantai yang diakibatkan oleh pergerakan sedimen, longshore current, dan gelombang (Opa 2011). Aktivitas seperti penebangan hutan mangrove, penambangan pasir, serta fenomena tingginya gelombang, dan pasang surut air laut menimbulkan dampak terjadinya abrasi atau erosi pantai (Wahyuningsih dkk, 2016).

Perubahan garis pantai terjadi pada skala detik sampai jutaan tahun (Sulaiman dan Soehardi 2008). Perubahan garis pantai sangat bervariasi antara satu tempat dengan tempat lainnya dan dipengaruhi oleh beberapa faktor (Istiono 2011). Menurut Hanafi (2005) garis pantai pada umumnya mengalami perubahan dari waktu ke waktu sejalan dengan perubahan alam seperti adanya aktivitas dari gelombang, angin, pasang surut, arus dan sedimentasi. Perubahan garis pantai juga terjadi akibat gangguan ekosistem pantai seperti pembuatan tanggul dan kanal serta bangunan-bangunan yang ada di sekitar pantai (Yulius dan Ramdhan 2013).

Berdasarkan penjelasan tersebut, Maka penulis tertarik untuk melakukan dari analisis perubahan garis pantai di 
Kecamatan Pantai Cermin Kabupaten Serdang Bedagai ini. Penganalisisan perubahan garis pantai tersebut akan dilihat dari citra landsat 8 dengan menggunakan aplikasi ArcGIS 10.5 . Jangka waktu yang kami pilih dari 2007-2017. Karena pada tahun-tahun inilah pembukaan pantai di Kecamatan Pantai Cermin untuk dijadikan obyek wisata tengah gencar dilaksanakan. Diharapkan nantinya setelah dilakukan penelitian ini diketahui laju perubahan garis pantai Kecamatan Pantai Cermin Kabupaten Serdang Bedagai, Laju perubahan maksimum dan minimum yang terjadi akibat abrasi dan akresi di wilayah pesisir Kecamatan Pantai Cermin Kabupaten
Serdang Bedagai serta dapat dijadikan masukkan dalam memprediksikan perubahan laju garis pantai Kabupaten Langkat.

\section{METODOLOGI PENELITIAN}

Metode yang digunakan dalam penelitian ini adalah metode deskriptif kuantitatif. penelitian deskriptif merupakan metode penelitian yang berusaha menggambarkan objek atau subjek yang diteliti sesuai dengan apa adanya, dengan tujuan menggambarkan secara sistematis fakta dan karakteristik objek yang diteliti secara tepat (Sukardi, 2008:162).

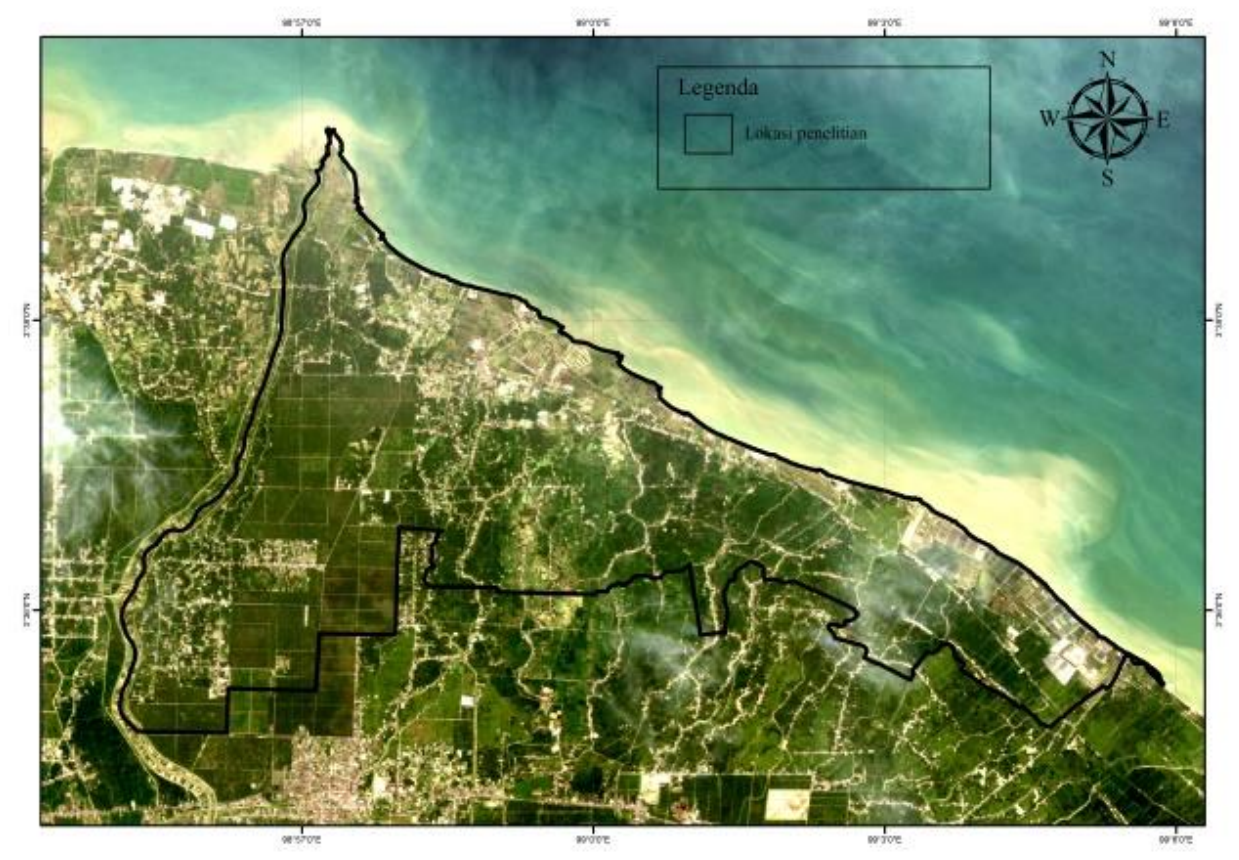

Gambar 1. Lokasi Penelitian

Wilayah penelitian analisis perubahan garis pantai adalah Kabupaten Serdang Bedagai khususnya di Pantai Cermin. Saat ini pantai di wilayah pesisir Kecamatan Pantai Cermin digunakan dalam berbagai kegiatan penggunaan lahan untuk menunjang pendapatan masyarakat setempat.

Data yang di pergunakan dalam penelitian perubahan garis pantai di wilayah Kecamatan Pantai Cermin ini adalah citra Landsat 5 pada perekaman tahun 2007 dan citra Landsat 8 pada perekaman 2017 yang diperoleh dari hasil download melalui laman USCS (United States Geological Survel) atau Earth Explorer. Software yang di pergunakan untuk mengolah data tersebut adalah dari Envi 4.7 untuk komposit data citra dan pan sharpened (penajaman citra), Arc GIS 10.5 untuk mengolah data citra termasuk digitasi garis pantai, dan menggabungkan dua data (union).

Proses pengolahan data untuk perubahan garis pantai di Kecamatan Pantai Cermin yang pertama dilakukan yaitu dengan melakukan komposit band (penggabungan beberapa band) citra Satelit Landsat 5 dan 8 di tahun 2007 dan 2017 serta penajaman citra antara citra hasil komposit dengan band pankromatik 
menggunakan software Envi 4.7. Tujuan dilakukannya pan sharpened untuk mempermudah interpretasi objek yang sebelumnya citra berukuran $30 \times 30 \mathrm{M}$ menjadi $15 \times 15 M$ per pixel. Selanjutnya dilakukan digitasi on screen garis pantai tiap data Satelit Landsat menyesuaikan dengan bentuk wilayah tersebut di tahun tersebut.
Hasil dari digitasi garis pantai dari masing-masing data citra Satelit Landsat 5 dan 8 di tahun 2007 dan 2017 di gabungkan dengan menggunakan fitur dari Geoprocessing yaitu Union pada ArcGIS. Secara sederhana proses penelitian tentang perubahan garis pantai di Kecamatan Pantai Cermin dapat dilihat pada gambar 2.

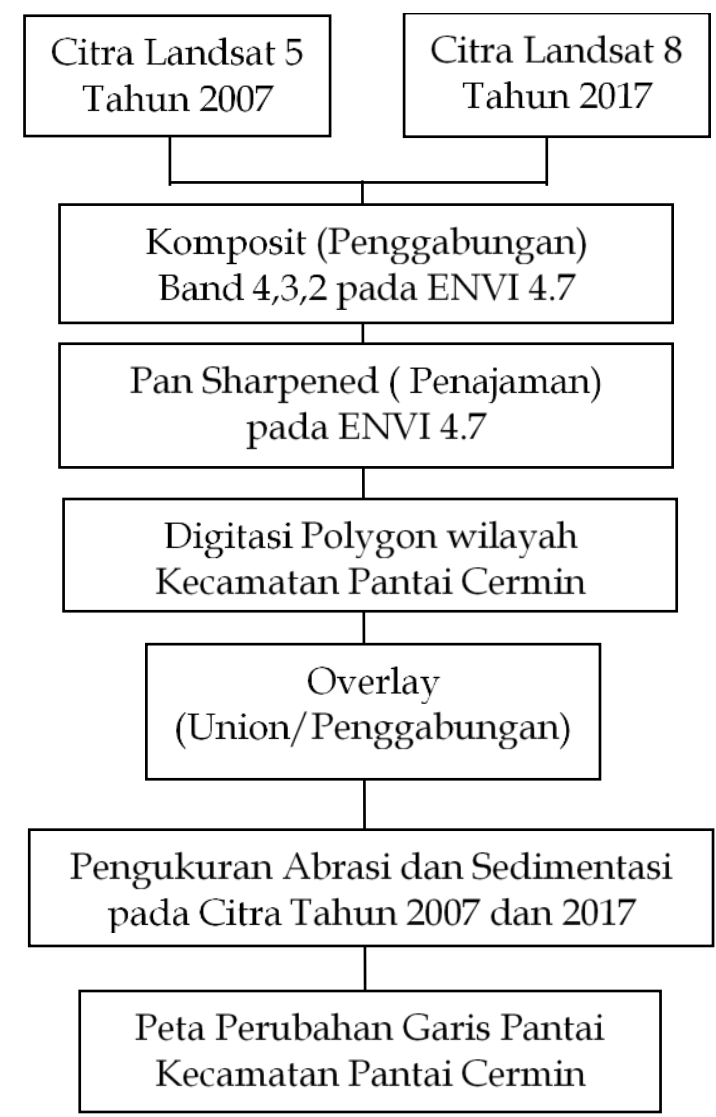

Gambar 2. Diagram alir pengukuran perubahan garis pantai wilayah Kecamatan Pantai Cermin tahun $2007 \& 2017$

\section{HASIL DAN PEMBAHASAN}

\section{Perubahan Garis Pantai di Kecamatan pantai}

\section{Cermin Tahun 2007 dan 2017}

Hasil interpretasi citra Landsat tahun 2007 dan 2017 yang telah di lakukan digitasi menunjukkan bahwa terjadi perubahan pada wilayah garis pantai di

Tabel 1. Luas Abrasi dan Sedimentasi wilayah Kecamatan Pantai Cermin pada tahun 2007 dan 2017. Perubahan tersebut berupa abrasi dan sedimentasi, luas abrasi dan sedimentasi yang terjadi cukup signifikan di Kecamatan Pantai Cermin dapat dilihat pada tabel berikut ini.

\begin{tabular}{cc}
\multicolumn{2}{c}{ Luas $\left(\mathrm{Km}^{2}\right)$} \\
\hline Abrasi & Sedimentasi \\
1.481 .798 & 1.249 .322 \\
\hline & Sumber : Hasil Penelitian 2018
\end{tabular}


Dari tabel di atas terlihat, bahwa pada rentang tahun 2007 dan 2017 penambahan daratan yang signifikan, berjumlah 12, $49322 \mathrm{Km}^{2}$. Sedangkan pada pengurangan daratan (abrasi) berjumlah $1481798 \mathrm{Km}^{2}$. terlihat bahwa dalam rentang tahun 10 tahun di dapat perubahan yang signifikan pada penambahan (sedimentasi) dan pengurangan (abrasi).

Perubahan garis pantai yang terjadi disebabkan oleh adanya abrasi dan akresi, penyebab utama abrasi dan akresi adalah aksi gelombang, angin dan pasang surut. Terdapat tiga proses dinamis penting yang mempengaruhi bentuk pantai yakni aksi gelombang, angin dan pasang surut. Proses yang paling penting adalah aksi gelombang. Saat bergerak menuju pantai, gelombang mengalami transformasi yang kemudian membangkitkan arus di dekat pantai. Arus yang bergerak di sepanjang pantai memindahkan sedimen sehingga menyebabkan perubahan garis pantai
(Doornkamp \& King, 1971). Untuk menyelesaikan persoalan perubahan garis pantai maka perlu adanya penelitian dan pengembangan model guna memprediksi pola perubahan garis pantai. Salah satu cara untuk memprediksi perubahan garis pantai yaitu melalui model numerik (Dean \& Zheng, 1997; Elfrink \& Baldock, 2002).

Hasil interpretasi yang dilakukan terhadap citra landsat 5 dan landsat 7 tahun 2007 serta 2017 di kawasan pesisir Kecamatan Pantai Cermin dan kemudian masing-masing hasil interpretasi tersebut di tumpang-tindikan (Overlay) sehingga menghasilkan beberapa garis pantai yang saling - silang. Hasil ini kemudian di pilah, kemudian dikelompokkan menjadi perubahan bersifat Abrasi atau perubahan bersifat Sedimentasi. Setelah dilakukan Identifikasi lokasi terjadinya abrasi dan sedimentasi pantai dengan cara menumpang susunkan (overlay) garis pantai tahun terlama dengan garis pantai tahun terkini.

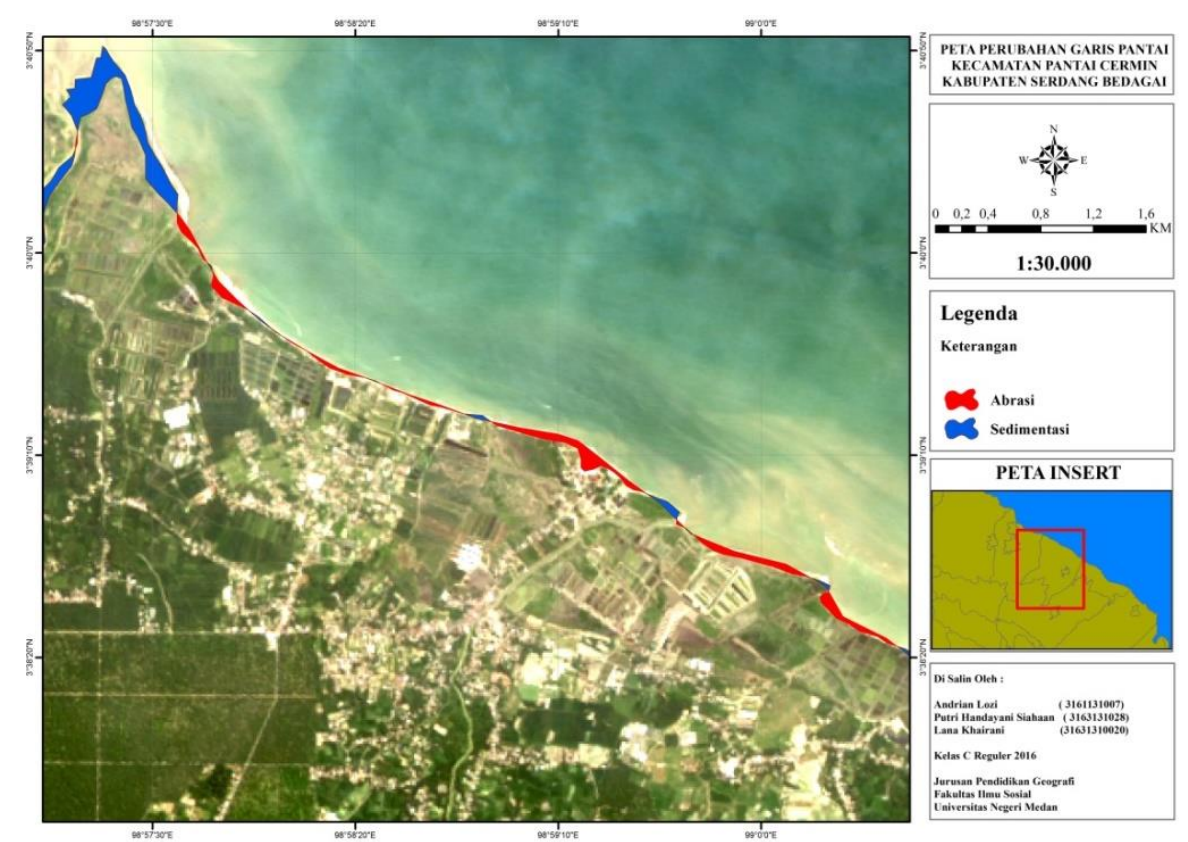

Gambar 3. Peta abrasi dan sedimentasi di Kecamatan Pantai Cermin tahun 2007 dan 2017 


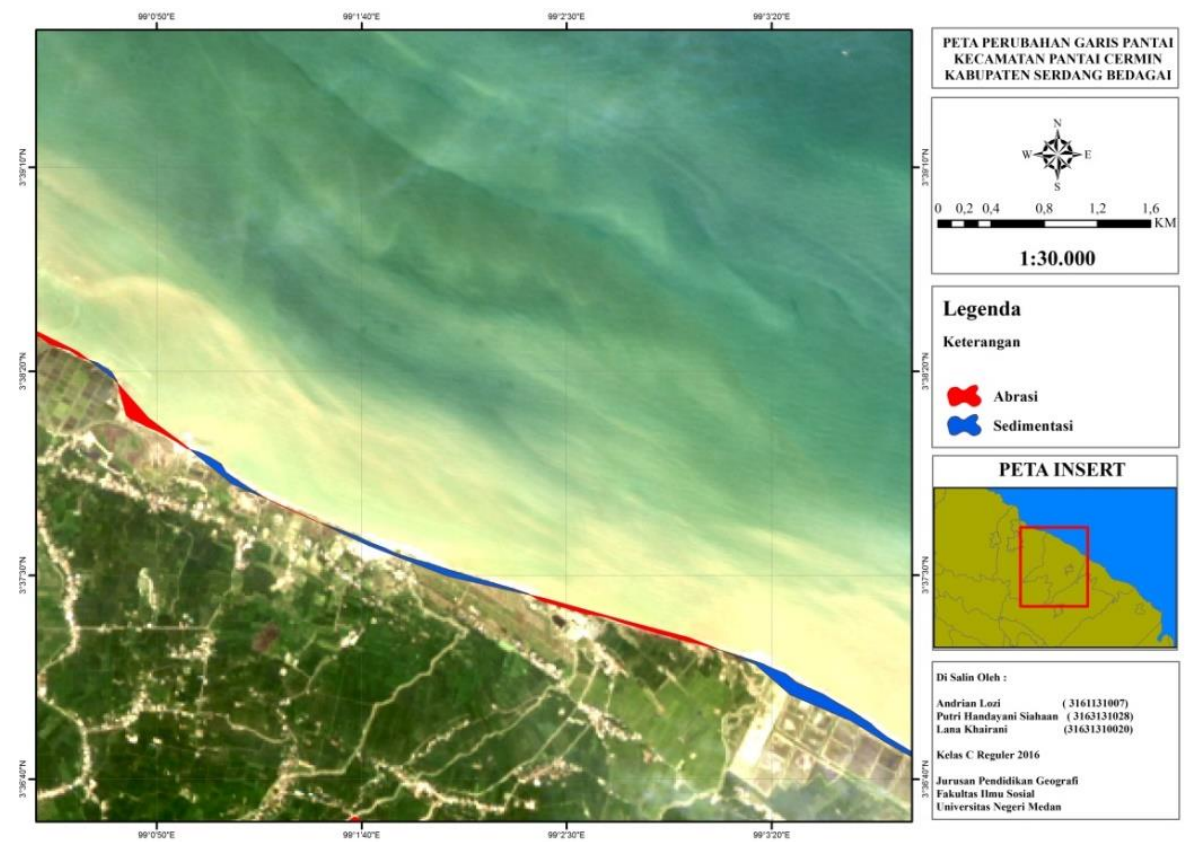

Gambar 4. Peta abrasi dan sedimentasi di Kecamatan Pantai Cermin tahun 2007 dan 2017

Berdasarkan gambar di atas menunjukkan bahwa sebagian besar kawasan pesisir di Kecamatan Pantai Cermin mengalami perubahan yang menunjukkan tingkat sedimentasi yang signifikan pada tahun 2007 dan tahun
2017. Perubahan ini ditunjukkan dengan keseluruhan wilayah terjadi penambahan daratan (sedimentasi), perubahan bersifat lebih bervariasi antara besarnya akresi dan abrasi.

\section{Perubahan Garis Pantai di Kecamatan Pantai Cermin tahun 2007 dan 2017}

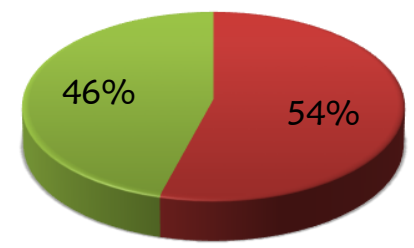

$\square$ Sedimentasi

$\square$ Abrasi

Gambar 1. Perbadingan Luas Sedimentasi dan Abrasi di Kecamatan Pantai Cermin

Berdasarkan hasil dari digitasi yang di lakukan dengan menggunakan software ArcGIS 10.5 maka di dapatkan luas wilayah di Kecamatan Pantai Cermin yang bertambah pada tahun 2007 dan 2017 mencapai $1481798 \mathrm{~km}^{2}$. Penambahan wilayah tersebut tersebar di sepanjang pesisir kawasan Kecamatan Pantai Cermin, serta dengan rata - rata pengikisan oleh abrasi air laut sebesar $1249322 \mathrm{Km}^{2}$ per tahunnya, dengan penambahan tepi pantai yang cukup signifikan per tahunnya.

\section{KESIMPULAN}

Perubahan garis pantai di Kecamatan Pantai Cermin dalam kurun waktu 10 tahun terakhir cukup membawa dampak yang signifikan, garis pantai yang terus bertambah setiap tahunnya akibat dari sedimentasiatau 
pengendapan bahan-bahan berubah tanah, pasir dan lainnya yang membuat garis pantai di Kecamatan Pantai Cermin bertambah luasnya sekitar $1481798 \mathrm{~km}^{2}$ dan pengikisan atau abrasi oleh air laut sebesar $1249322 \mathrm{Km}^{2}$. Perubahan garis pantai yang terjadi disebabkan oleh adanya abrasi dan akresi, penyebab utama abrasi dan akresi adalah aksi gelombang, angin dan pasang surut. Terdapat tiga proses dinamis penting yang mempengaruhi bentuk pantai yakni aksi gelombang, angin dan pasang surut. Proses yang paling penting adalah aksi gelombang. Saat bergerak menuju pantai, gelombang mengalami transformasi yang kemudian membangkitkan arus di dekat pantai.

\section{DAFTAR PUSTAKA}

Awaliah, O.W., Sakka, dan Hamzah, M.A. 2013. Modul Perubahan Garis Pantai Dengan Metode One-Line Model (Studi Kasus : Pantai Mangarabombang -Galesong Selatan, Kabupaten Takaliar). Universitas Hasanudin.

Dean RG, Zheng J. 1997. Numerical model and intercomparisons of beach profil evolution. J Coast Eng 30 : 169-201.

Doornkamp J D, King MAC. 1971. Spacial Analysis in Geomorphologycal. Harvard and Low Publisher. inc. New York.

Hanafi, M. 2005. Hubungan Faktor Perilaku Manusia, Faktor Alam Dengan Perubahan Garis Pantai Untuk Optimisasi Pengelolaan Wilayah Pesisir Di Kabupaten Indramayu Jawa Barat.

Istiono, Feri. 2011. Evaluasi Perubahan Garis Pantai Dan Tutupan Lahan Kawasan Pesisir Dengan Data Penginderaan Jauh (Studi Kasus: Kawasan Pesisir Pasuruan, Probolinggo, dan Situbondo). ITS Undergraduate Theses. Surabaya: Institut Teknologi Sepuluh Nopember.

Kasim, F. 2012. Pendekatan beberapa metode dalam monitoring perubahan garis pantai menggunakan dataset penginderaan jauh Landsat dan SIG. Jurnal Ilmiah Agropolitan, 5, 620-635.

Opa, ET. 2011. Perubahan Garis Pantai Desa Bentenan Kecamatan Pusomaen, Minahasa Tenggara. Jurnal Perikanan dan Kelautan Tropis Vol. VII-3.
Solihuddin, T. (2006). Karakteristik Pantai dan Potensi Bencana Geologi Pantai Bilungala, Gorontalo. Jurnal IImiah Globe, 13(2), 112-120.

Sukardi. 2008. Metodologi Penelitian Pendidikan Kompetensi dan Praktiknya. Jakarta: PT. Bumi Aksara

Sulaiman, A., Soehardi, I. 2008. Pendahuluan Geomorfologi Pantai. BPPT. Jakarta.

Taofiqurohman, A., \& Ismail, M. F. A. (2012). Analisis Spasial Perubahan Garis Pantai di Pesisir Kabupaten Subang, Jawa Barat. Jurnal Perikanan dan Kelautan Tropis, 8(3), 75-80.

Tawas, H.J, Pingkan A.K.P. 2016. Pengaruh Gelombang Besar Terhadap Kerusakan Garis Pantai. Jurnal Tekno. 14 (65): 65 71. Manado: Universitas Sam Ratulangi.

Undang-Undang Republik Indonesia Nomor 22 tahun 1999 Tentang Pemerintahan Daerah. Bab II Pasal 3 Mengenai Pembagian Daerah.

Wahyuningsih, D.S., Maulana, E., Wulan, T.R., Ambarwulan, W., Putra, M.D., Ibrahim, F., Setyaningsih, Z., Putra, A.S. 2016. Efektivitas Upaya Mitigasi Abrasi Berbasis Ekosistem di Kabupaten Kulonprogo, Daerah Istimewa Yogyakarta. Prosiding Seminar Nasional Kelautan 2016 Universitas Trunojoyo Madura. ISBN: 978-60219131-4-7.

Yulius., M. Ramdhan. 2013. Perubahan Garis Pantai di Teluk Bungus Kota Padang, Provinsi Sumatera Barat Berdasarkan Analisis Citra Satelit. Jurnal Ilmu dan Teknologi Kelautan Tropis. 5 (2): 417-427. Badan Penelitian dan Pengembangan Kelautan dan Perikanan-KKP. 
